\title{
Skin Photo-Protective and Anti-ageing Activity of Consciousness Energy Healing Treatment Based Herbomineral Formulation
}

\author{
Bonnie P. Hegarty-Diaz ${ }^{1}$, Mahendra Kumar Trivedi ${ }^{1}$, Alice Branton ${ }^{1}$, Dahryn Trivedi ${ }^{1}$, \\ Gopal Nayak ${ }^{1}$, Mayank Gangwar', Snehasis Jana ${ }^{2, *}$ \\ ${ }^{1}$ Trivedi Global, Inc., Henderson, Nevada, USA \\ ${ }^{2}$ Trivedi Science Research Laboratory Pvt. Ltd., Bhopal, Madhya Pradesh, India
}

Email address:

publication@trivedisrl.com (S. Jana)

${ }^{*}$ Corresponding author

\section{To cite this article:}

Bonnie P. Hegarty-Diaz, Mahendra Kumar Trivedi, Alice Branton, Dahryn Trivedi, Gopal Nayak, Mayank Gangwar, Snehasis Jana. Skin Photo-Protective and Anti-ageing Activity of Consciousness Energy Healing Treatment Based Herbomineral Formulation. Journal of Diseases and Medicinal Plants. Vol. 3, No. 3, 2017, pp. 49-59. doi: 10.11648/j.jdmp.20170303.12

Received: March 27, 2017; Accepted: April 25, 2017; Published: May 8, 2017

\begin{abstract}
The objective of this study was to evaluate the impact of The Trivedi Effect ${ }^{\circledR}$ - Consciousness Energy Healing Treatment based herbomineral formulation on various skin parameters using HFF-1, HaCaT, and B16-F1 cell lines. The test formulation was composed of minerals (zinc, selenium, and molybdenum), and L-ascorbic acid along with the mixture of Centella asiatica extract and tetrahydrocurcumin (THC). Test formulation and DMEM were divided into two equal parts, one was treated with the Biofield Energy Treatment by Bonnie P. Hegarty-Diaz and denoted as treated, while other part was coded as untreated groups. MTT assay result showed that the test formulation was found safe and nontoxic at tested concentration 40 $\mu \mathrm{g} / \mathrm{mL}$. Fibroblast cell proliferation assay showed significant increased cell proliferation by $26.83 \%$ at $8.75 \mu \mathrm{g} / \mathrm{mL}$ in BTDMEM + BT-Test formulation group compared to the untreated group. The level of collagen was significantly increased by $22.05 \%$ and $22.24 \%$ (at $2.5 \mu \mathrm{g} / \mathrm{mL}$ ) in BT-DMEM + UT-Test formulation and BT-DMEM + BT-Test formulation groups, respectively. However, collagen amount was increased by $11.08 \%$ and $9.52 \%$ in BT-DMEM + UT-Test formulation and BTDMEM + BT-Test formulation groups, respectively at $1.25 \mu \mathrm{g} / \mathrm{mL}$, compared to untreated group. Similarly, elastin synthesis was increased in the BT-DMEM + UT-Test formulation group by $19.98 \%, 72.54 \%$ and $105.04 \%$ at the concentrations 10,5 , and $2.5 \mu \mathrm{g} / \mathrm{mL}$, respectively compared to the untreated group. However, level of hyaluronic acid was increased by $5.19 \%$ at $0.625 \mu \mathrm{g} / \mathrm{mL}$ in UT-DMEM + BT-Test formulation group compared with the untreated group. Besides, melanin synthesis inhibition was found to be inhibited by $14.80 \%$ and $17.40 \%$ at $0.125 \mu \mathrm{g} / \mathrm{mL}$ in the UT-DMEM + BT-Test formulation and BTDMEM + UT-Test formulation groups, respectively compared with the untreated group in B16-F10 melanoma cell line. Antiwrinkling activity in HFF-1 cells showed improve cell viability in all the groups at various concentrations, i.e. in UT-DMEM + BT-Test formulation, BT-DMEM + UT-Test formulation, and BT-DMEM + BT-Test formulation group by $10.69 \%, 6.9 \% 3$, and $11.86 \%$, respectively at $0.625 \mu \mathrm{g} / \mathrm{mL}$ compared with the untreated group. In addition, wound healing scratch assay data suggest significantly higher cellular migration of fibroblast and keratinocytes cells in HFF-1 and HaCaT cells lines, respectively. In conclusion, Biofield Energy Healing (The Trivedi Effect ${ }^{\mathbb{B}}$ ) based test formulation and DMEM could be beneficial against various skin disorders such psoriasis, seborrheic dermatitis, skin cancer, rashes from bacterial or fungal infections and can be significantly used as anti-wrinkling, skin-whitening, anti-ageing, and rejuvenating action.
\end{abstract}

Keywords: Consciousness Energy Healing Treatment, Extracellular Matrix, HaCaT, HFF-1, Hyaluronic Acid, Scratch Assay, Tetrahydrocurcumin 


\section{Introduction}

The use of herbomineral formulations have been reported with excellent outcomes for general skin health. Herbomineral products are regarded as a powerful combination of some rare herbs and minerals. The formula is based on the basis of scientific information and their clinical significance. Herbal based products have been used as traditional medicine from thousands of years ago, while most of the current populations are found dependent on various forms, like drugs, cosmetics, and agrochemicals [1]. These formulations have been reported against various chronic diseases through different cellular, molecular, genetic mechanisms and pathways. Most of the cosmetics used against skin darkening action are based on herbal active principle [2], and their high demands are due to lower incidence of adverse effects compared with the chemical compounds [3-6]. In addition, countless photo-aging products, antioxidant agents (i.e. vitamin $\mathrm{B}_{3}, \mathrm{C}$, and $\mathrm{E}$ ), invasive measures such as gene therapy, chemical peels, and several devices such as laser energy, injectable, etc. are used for skin health and rejuvenation $[7,8]$.

On the basis of available scientific literature, a new proprietary herbomineral formulation was formulated for overall skin health. It consists of zinc chloride, sodium selenate, sodium molybdate, L-ascorbic acid, tetrahydrocurcumin (THC), and extract of Centella asiatica (commonly known as Jal Brahmi). THC is the major active metabolite of curcumin [9] with strong antioxidant property [10-12]. C. asiatica is well known medicinal herb reported for wound healing action along with significant uses in skin care products. Besides, vitamins (such as Vit-A, E and C) play an important role in skin health, anti-wrinkling, and wound healing action [13]. In addition, use of minerals as active ingredients such as zinc, copper, and selenium are widely used in cosmetology. These selected ingredients have been reported with strong antimicrobial, antioxidant, and free radical scavenging effects with improved extra cellular component synthesis [14, 15].

Biofield Energy Healing, one form of Complementary and Alternative Medicine (CAM) has been reported with outstanding results in many clinical and pre-clinical studies. In addition, the National Center for Complementary and Alternative Medicine (NCCAM), defined Biofield therapies in the subcategory of Energy Therapies. Biofield is the scientifically chosen term for the biologically formed electromagnetic and subtle energy field, which provides regulatory and communication functions within the organism [16]. However, Biofield Energy might exist in different forms like kinetic, potential, electrical, magnetic, and nuclear. However, Biofield Energy Healing therapies have been reported with significant outcomes against many patient [1720]. Therefore, as an alternate approach, Biofield Energy Healing is increasingly accepted to promote human wellness. Biofield Energy Treatment (The Trivedi Effect ${ }^{\mathbb{R}}$ Consciousness Energy Healing Treatment) has been reported with significant results in nonliving materials and living organisms. The Trivedi Effect ${ }^{\circledR}$ has been reported with significant outcome in the field of microbiology [21-23], agriculture science [24-26], biotechnology [27, 28], and materials science [29-31]. Based on the outstanding applications of Biofield Energy Treatment and use of herbomineral formulation in skin care treatment, present work was designed to evaluate the Biofield Energy Healing based herbomineral formulation against various skin parameters in human foreskin fibroblast (HFF-1), human keratinocytes $(\mathrm{HaCaT})$ and mouse melanoma cell lines (B16F10).

\section{Materials and Methods}

\subsection{Chemicals and Reagents}

The components of test formulation such as zinc chloride was purchased from TCI, Japan, sodium selenate from AlfaAesar, USA, while sodium molybdate from Sigma-Aldrich. Tetrahydrocurcumin and Centella asiatica extract were procured from Novel Nutrients Pvt. Ltd., India and Sanat Products Ltd., India respectively. L-ascorbic acid as a positive control was purchased from Alfa-Aesar, while kojic acid and 3-(4, 5-diamethyl-2-thiazolyl) 2, 5 diphenyl-2 $H$ tetrazolium) (MTT) were purchased from Sigma Chemical Co. (St. Louis, MO). Epidermal growth factor (EGF) was procured from Gibco, ThermoFisher, USA. ELISA kits for the estimation of extracellular matrix component were procured from CUSABIO and CusAb Co. Pvt. Ltd, USA. Fetal bovine serum (FBS) and DMEM were purchased from Gibco, USA. Antibiotics solution (Penicillin-Streptomycin) were procured from Hi-Media, India, while Direct Red 80 and EDTA were purchased from Sigma, USA. All the other chemicals used in this experiment were analytical grade procured from local vendors.

\subsection{Cell Culture}

HFF-1 (human foreskin fibroblast) cells were procured from American Type Culture Collection (ATCC), USA, originated from normal human skin fibroblast cells. B16-F10 (mouse melanoma) and $\mathrm{HaCaT}$ (human keratinocytes) cells were procured from National Centre for Cell Science (NCCS), Pune, India. HFF-1, HaCaT, and B16-F10 cell lines were maintained in the growth medium DMEM supplemented with $15 \%$ FBS, with added antibiotics penicillin $(100 \mathrm{U} / \mathrm{mL})$ and streptomycin $(100 \mu \mathrm{g} / \mathrm{mL})$. The growth condition of cell lines were $37^{\circ} \mathrm{C}, 5 \% \mathrm{CO}_{2}$, and $95 \%$ humidity. L-ascorbic acid (for ECM, UV-B protection, and wound healing assay) at the concentrations ranges from 10 $\mu \mathrm{M}$ to $1000 \mu \mathrm{M}$, while kojic acid (for melanin) concentrations ranges from $1 \mathrm{mM}$ to $10 \mathrm{mM}$. FBS $(0.5 \%)$ was used in cell proliferation assay in BrdU assay, while EGF $10 \mu \mathrm{M}$ used in non-cytotoxic dose concentration in MTT assay. 


\subsection{Experimental Design}

The experimental groups consisted of cells in normal control group, vehicle control group $(0.05 \%$ DMSO $)$, positive control group (L-ascorbic acid/kojic acid/EGF/FBS) and experimental tested groups. Experimental groups included the combination of Biofield Energy Treated and untreated test formulation/DMEM. It consisted of four major treatment groups on specified cells with the UT-DMEM + UT-Test formulation, UT-DMEM + Biofield Treated test formulation (BT-Test formulation), BT-DMEM + UT-Test formulation, and BT-DMEM + BT-Test formulation.

\subsection{Energy of Consciousness Treatment Strategies}

The test formulation and DMEM were divided into two parts. One part of the test formulation was treated with the Biofield Energy by renowned Biofield Energy Healer (also known as The Trivedi Effect ${ }^{\circledR}$ ) and coded as the Biofield Energy Treated formulation, while the second part of the test formulation did not receive any sort of treatment and was defined as the untreated test formulation. This Biofield Energy Treatment was provided by Bonnie P. Hegarty-Diaz, who participated in this study and performed the Biofield Energy Treatment remotely. Biofield Energy Healer was remotely located in the USA, while the test formulation was located in the research laboratory of Dabur Research Foundation near New Delhi, Ghaziabad, India. This Biofield Energy Treatment was administered for 5 minutes through the Healer's unique Energy Transmission process remotely to the test formulation under laboratory conditions. The Biofield Energy Healer, Bonnie P. Hegarty-Diaz, in this study never visited the laboratory in person, nor had any contact with the herbomineral samples and medium. Further, the control group was treated with a sham healer for comparative purposes. The sham healer did not have any knowledge about the Biofield Energy Healing Treatment. After that, the Biofield Energy treated and untreated samples were kept in similar sealed conditions for experimental study.

\subsection{Determination of Non-cytotoxic Concentrations}

The cell proliferation in cell lines such as HFF-1, HaCaT, and B16-F10 were performed by MTT assay. The cells counted and plated in 96 well plates at the density corresponding to $5 \times 10^{3}$ to $10 \times 10^{3}$ cells/well/ $180 \mu \mathrm{L}$ of cell growth medium. The cells were incubated overnight under specific growth conditions that were allowed the cell recovery and exponential growth, which were subjected to serum stripping or starvation. The cells were subsequently treated to the Biofield Energy Treated and untreated groups of test formulation/DMEM at a range of concentrations $(0.008$ to $10 \mu \mathrm{g} / \mathrm{mL})$ and ascorbic acid $(10$ and $50 \mu \mathrm{M})$ followed by incubation from 24 to 72 hours in $\mathrm{CO}_{2}$ incubator at $37^{\circ} \mathrm{C}, 5 \% \mathrm{CO}_{2}$ and $95 \%$ humidity. Further, serum free MTT media $(20 \mu \mathrm{L}$ of $5 \mathrm{mg} / \mathrm{mL})$ was added to each well followed by incubation for 3 hours at $37^{\circ} \mathrm{C}$. The supernatant was aspirated and $150 \mu \mathrm{L}$ of DMSO was added to each well to dissolve the formazan crystals. Thereafter, the absorbance of each well was recorded at $540 \mathrm{~nm}$ using Synergy HT micro plate reader, BioTek, USA. The concentrations that exhibited percentage cytotoxicity of less than $30 \%$ was considered as non-cytotoxic [32].

\subsection{Effect of the Test Formulation on Human Foreskin Fibroblast (HFF-1) Cell Proliferation Using BrdU Method}

HFF-1 cells were counted using hemocytometer and plated in 96 well plate at the density corresponding to $1 \times 10^{3}$ to 5 X $10^{3}$ cells/well in DMEM supplemented with $15 \%$ FBS. The cells/plates were then incubated overnight under growth conditions so as to allow cell recovery and exponential growth. Following overnight incubation, the above cells were subjected to serum starvation. Following serum starvation, the cells were treated with non-cytotoxic concentrations of test formulation in different defined experimental groups and positive control. Following 24 to 72 hours of incubation with the test substance and positive control, the plates were taken out and BrdU (5-bromo-2'-deoxyuridine) estimated using Cell Proliferation ELISA, BrdU estimation kit (ROCHE 11647229001 ) as per manufacturer's instructions.

\subsection{Estimation of Extracellular Matrix Component Synthesis}

Synthesis of extracellular matrix components (i.e. collagen, elastin and hyaluronic acid) in HFF-1 cell line was estimated for determining the potential of test formulation to improve skin strength, overall suppleness/elastin, and hydration level. HFF-1 cells were counted using hemocytometer and plated in 48 well plate at the density corresponding to $10 \times 10^{3}$ cells/well in DMEM supplemented with $15 \%$ FBS. The cells were then incubated overnight under specified growth conditions followed by cells to serum stripping. Further, the cells were treated with the test item treatment at different experimental combination groups with DMEM group viz. vehicle control (DMSO, $0.05 \%$ ), and positive control (ascorbic acid, at $10 \mu \mathrm{M})$. Further, 72 hours of incubation with the test items and positive control, the supernatants from all the cell plates were taken out and collected in pre labeled centrifuge tubes for the estimation of elastin and hyaluronic acid levels. However, the corresponding cell layers were processed for the estimation of collagen levels using Direct Sirius red dye binding assay. Elastin and hyaluronic acid were estimated using ELISA kits from Cusabio Biotech Co. Ltd., Human Elastin ELN Elisa kit 96T and Human Hyaluronic Acid Elisa kit 96T, respectively [33].

\subsection{Estimation of Melanin Synthesis - Skin Depigmentation Effect}

B16-F10 cells were used for melanin synthesis estimation, cells were counted using hemocytometer and plated in 90 $\mathrm{mm}$ culture dish at the density corresponding to $2 \mathrm{X} 10^{6} / 6$ $\mathrm{mL}$ in culture plates. Further, the cells were incubated overnight under specified growth conditions and allowed for cell recovery and exponential growth. After incubation, the 
cells were treated with $\alpha$-melanocyte-stimulating hormone $(\alpha-\mathrm{MSH})$ for a time point ranging from 4 to 24 hours for stimulation of intracellular melanin synthesis. Further, the cells were incubated with $\alpha-\mathrm{MSH}$, and then treated with concentration at $0.625,1.25$ and $2.5 \mu \mathrm{g} / \mathrm{mL}$ of test formulation with DMEM for a time period from 48 to 96 hours. After incubation, intracellular melanin was extracted in $\mathrm{NaOH}$ and the absorbance was recorded at $405 \mathrm{~nm}$. The level of melanin was extrapolated using standard curve obtained from purified melanin [34].

\subsection{Anti-Wrinkling Effects of Test Formulation on HFF-1 Cells Against UV-B Induced Stress}

UV-B induced stress was evaluated in HFF-1 cells and cell viability was estimated in the presence of test formulation. The cells were counted using hemocytometer and plated in 96 well plate at the density corresponding to $5 \times 10^{3}$ to $10 \mathrm{X}$ $10^{3}$ cells/well in DMEM supplemented with $15 \%$ FBS cells/plates, which were incubated overnight under growth conditions to allow cell recovery and exponential growth. The cells were treated with non-cytotoxic concentrations of test formulation for 2 to 24 hours. After treatment, the cells were subjected to lethal dose of UV-B irradiation (200 $\left.\mathrm{mJ} / \mathrm{cm}^{2}\right)$ that can lead to approx. $50 \%$ cytotoxicity $(302 \mathrm{~nm}$, CL-1000 M, UVP, USA) [35]. The percent cell viability was assessed using formula (1)-

$$
\% \text { Cell viability }=\left(\mathrm{X}^{*} 100\right) / \mathrm{R}
$$

Where X represents the absorbance of cells corresponding to positive control and test groups, and $\mathrm{R}$ represents the absorbance of cells corresponding to baseline (control cells) group.

\subsection{Wound Healing Scratch Assay}

HFF-1 and HaCaT cell lines were counted using hemocytometer and plated in 12 well plates at the densities $0.08 \times 10^{6} /$ well $/ \mathrm{mL}$ of cell growth medium. The cells were incubated overnight under growth conditions and allowed cell recovery and exponential growth. After overnight incubation, the cells were subjected to the serum starvation in DMEM for 24 hours. Mechanical scratch wound was created in the near confluent monolayer of cells by gently scrap with the sterile $200 \mu \mathrm{L}$ micropipette tip. The cells were rinsed with serum free DMEM and the Biofield Energy treated test formulation. The scratched area was monitored for a time period ranging from 0 to 48 hours for closure of wound area. The photomicrographs were done at the selected time point's for quantitative assessment of migrated cells using digital camera, which was connected to the inverted microscope. All the observations were calculated and compared with positive and vehicle control [36].

\subsection{Statistical Analysis}

Each experiments were carried out in three independent assay and was represented as mean values with standard deviation. Student's t-test was used to compare two groups to judge the statistical significance. For multiple group comparison, one-way analysis of variance (ANOVA) was used followed by post-hoc analysis using Dunnett's test. Statistically significant values were set at the level of $\mathrm{p} \leq 0.05$.

\section{Results and Discussions}

\subsection{Non-cytotoxic Effect of the Test Formulation on Cell Lines}

The cytotoxic effect of the test formulation was tested on three cell lines i.e. HFF-1, HaCaT and B16-F10 in presence of positive control ascorbic acid $(10 \mu \mathrm{M})$ and EGF $(10 \mathrm{ng} / \mathrm{mL})$ were used at defined concentrations for estimation of percentage cell viability. The results of percentage cell viability in all the tested cell lines showed that the cell viability range of $64 \%$ to $121 \%$ in different test formulation group with DMEM, while for ascorbic acid it was found more than $89 \%$ (Figure 1). These data suggest that herbomineral formulation was found safe at all the tested dose ranges up to maximum of $40 \mu \mathrm{g} / \mathrm{mL}$ against the tested cell lines.
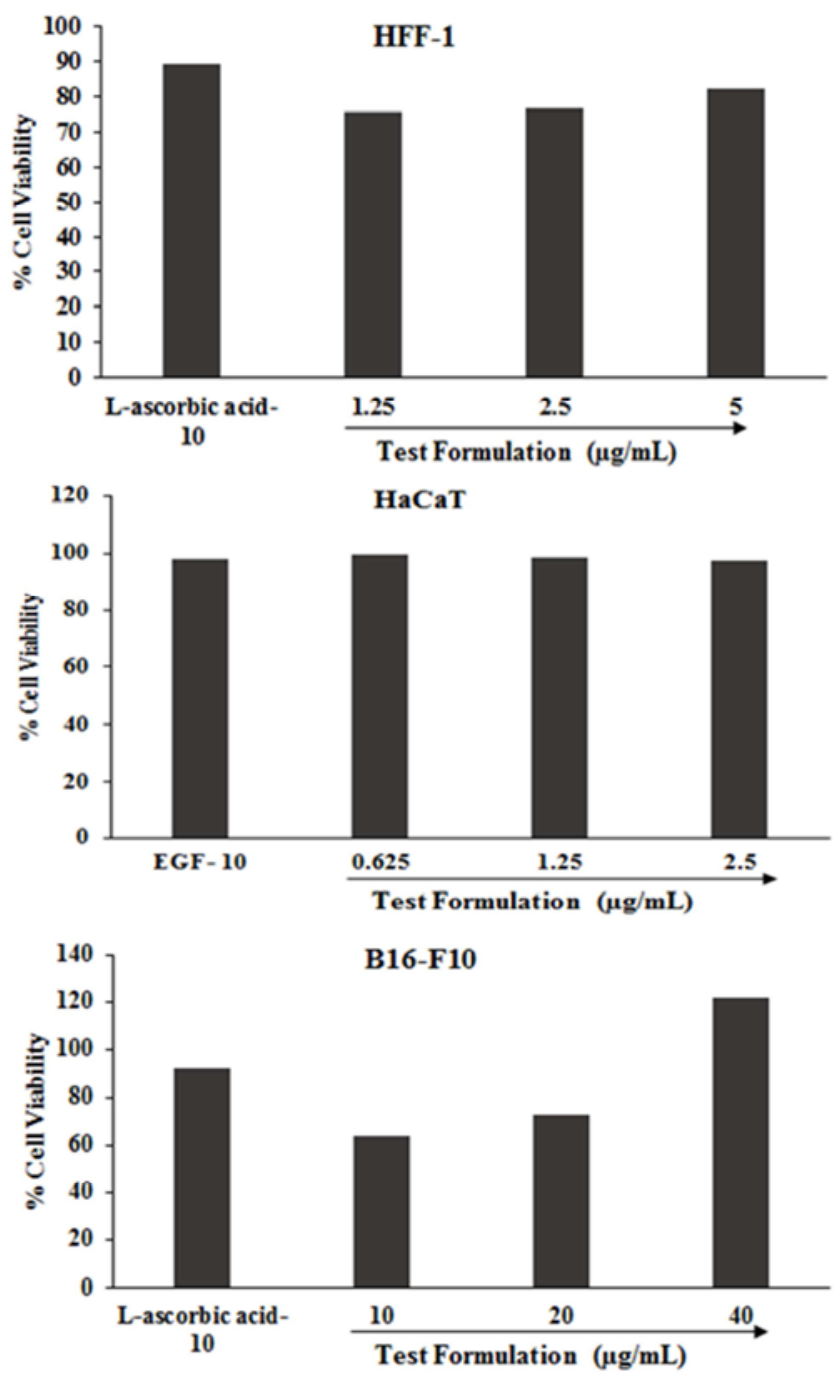

Figure 1. Effect of the test formulation on HFF-1, HaCaT, and B16-F10 cell lines for cell viability for 72 hours. EGF-10: Epidermal growth factor (10 $\mu M)$. 


\subsection{Effect of the Biofield Energy Treated Test Formulation on Human Foreskin Fibroblast Cell Proliferation (BrdU Method)}

The results of human fibroblast cell proliferation using BrdU method at different combinations of herbomineral formulation with DMEM on percentage cellular proliferation of HFF-1 cells after 48 hours of incubation is represented in Figure 2. In the presence of FBS, significant increase in cell proliferation rate was observed by $250 \%$. The study results showed that FBS significantly improved the proliferation rate compared with normal and vehicle control group by $150 \%$. Besides, the Biofield Energy Treated groups have shown significant increase in cellular proliferation in all the groups at 2.13 and $8.75 \mu \mathrm{g} / \mathrm{mL}$ concentration. However, at 17.5 $\mu \mathrm{g} / \mathrm{mL}$, lower cellular proliferation rate was observed in HFF-1 cells compared with other two tested concentrations. The increased proliferation rate in the BT-DMEM + BT-Test formulation group showed significant proliferation by $26.83 \%$ at $8.75 \mu \mathrm{g} / \mathrm{mL}$, compared with the untreated UTDMEM + UT-Test formulation group. This suggest that the Biofield Energy Treatment results in significant increase in cellular proliferation rate in HFF-1 cells at $8.75 \mu \mathrm{g} / \mathrm{mL}$ using BrdU assay.

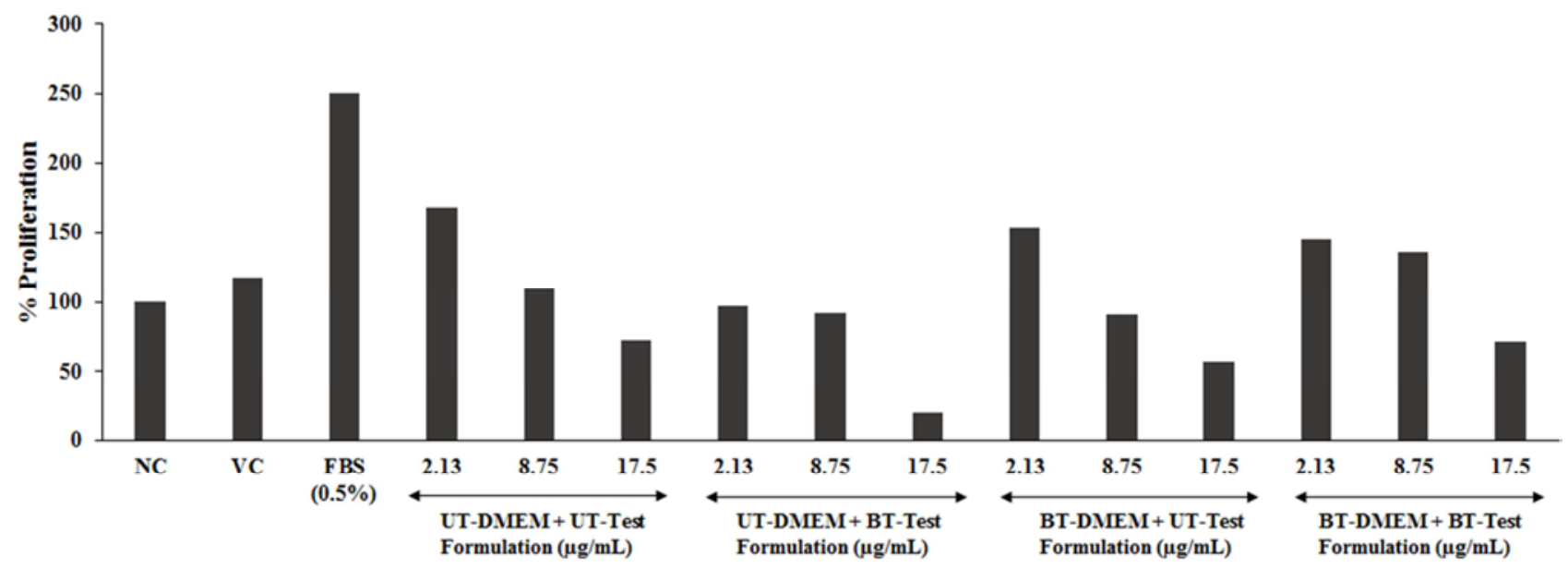

Figure 2. Effect of the Biofield Energy Treated test formulation with DMEM on cellular proliferation in HFF-1 cells after 48 hours. NC: Normal control; VC: Vehicle control: FBS: Fetal bovine serum; UT: Untreated; BT: Biofield treated.

\subsection{Analysis of Extracellular Matrix Component Synthesis}

The extra cellular matrix components (ECM) were assessed in order to identify the skin strength, hydration level and overall elasticity using Biofield Energy Treated Test formulation in HFF-1 cell line. The results of the study are presented as collagen, elastin and hyaluronic acid levels.

Collagen analysis

The effect of the Biofield Energy Treated test formulation/DMEM on collagen level showed significant increase in the collagen content at various experimental concentrations on HFF-1 cell line. Collagen is considered as major skin components and most abundant protein for skin health, structure and most abundant fibrous protein present in ECM. Experimental results of collagen with respect to ascorbic acid and Biofield Energy Treated test formulation/DMEM groups are presented in Figure 3. Ascorbic acid $(10 \mu \mathrm{M})$ showed significant increased collagen content by $54.77 \%$, while Biofield Treated test formulation at dose range from 0.625 to $2.5 \mu \mathrm{g} / \mathrm{mL}$ reported with the significant increased percentage of collagen amount.

However, among the tested experimental test formulation groups, the first group UT-DMEM + BT-Test formulation reported with significant increase collagen level at 1.25 and $0.625 \mu \mathrm{g} / \mathrm{mL}$ showed $5.45 \%(94.68 \pm 4.61 \mu \mathrm{g} / \mathrm{mL})$ and $9.20 \%(104.63 \pm 9.13 \mu \mathrm{g} / \mathrm{mL})$, respectively compared to the UT-DMEM + UT-Test formulation group. Similarly, at
$0.625 \mu \mathrm{g} / \mathrm{mL}$ in BT-DMEM + UT-Test formulation and BTDMEM + BT-Test formulation group, showed increased collagen level by $6.72 \%$ and $8.03 \%$, respectively. However, at $1.25 \mu \mathrm{g} / \mathrm{mL}$ in BT-DMEM + UT-Test formulation and BT-DMEM + BT-Test formulation group, showed increase collagen level by $11.08 \%$ and $9.52 \%$, respectively. Similarly, at $2.5 \mu \mathrm{g} / \mathrm{mL}$ in BT-DMEM + UT-Test formulation and BT-DMEM + BT-Test formulation group, showed increased collagen level by $22.05 \%$ and $22.24 \%$, respectively. The experimental data showed significantly increase in collagen level after treatment with Biofield Energy Treated test formulation. Hence, from the present parameter of ECM, collagen level was overall improved along with its synthesis after Biofield Energy Healing Treatment with respect to the respective untreated group. It might be expected that collagen synthesis via procollagen peptides and cross-linking (aldol reaction) among various tropocollagen molecules was increased, which results in formation of collagen fibrils. This will provide strength and structure to the skin and other tissues [37, 38]. It might be expected that Biofield Energy Treatment might improve the tropocollagen molecules, which showed increased collagen fibril and its content. These study data suggest that Biofield Energy (The Trivedi Effect ${ }^{\circledR}$ ) treated test formulation and DMEM showed remarkable increase in collagen level that might be useful for application in skin health, strength, and structure and wound healing. 


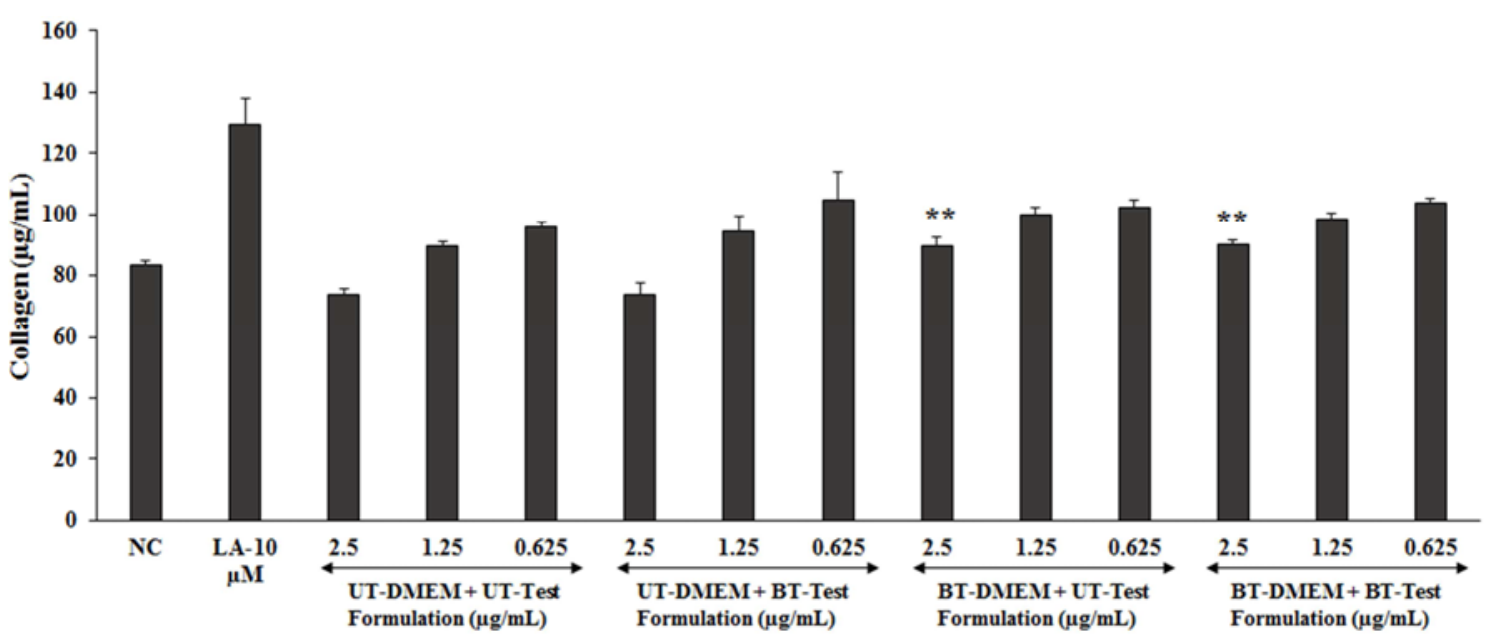

Figure 3. Concentration-dependent effects of test formulation on human dermal fibroblast (HFF-1) cell line for collagen level, extracellular matrix component. ${ }^{* *} p \leq 0.01$ statistical comparison with respect to untreated group using one way ANOVA (Dunnett's test). NC: Normal control; LA-10: L-Ascorbic acid at $10 \mu M$ concentration; UT: Untreated; BT: Biofield treated.

\section{Assessment of elastin.}

The impact of the Biofield Energy Healing Treatment on herbomineral formulation was evaluated for change in the elastin level. Elastin helps to retain shape in the body tissue and very elastic tissue of the body. Elastin is one of the important part of the ECM, it forms tight junction with collagen fibrils, which helps to maintain the cellular integrity [39]. The results (Figure 4.) showed a significant enhancement in the elastin synthesis in the Biofield Energy Healing based herbomineral in HFF-1 cell line. Ascorbic acid $(50 \mu \mathrm{M})$ group showed significant increase elastin content by $55.30 \%$ compared with the normal control group. However, among other tested groups, BT-DMEM + UT-Test formulation group showed significant increase percentage by
$19.98 \%, 72.54 \%, 105.04 \%$ at concentrations 10,5 , and 2.5 $\mu \mathrm{g} / \mathrm{mL}$, respectively. Besides, BT-DMEM + BT-Test formulation group showed increase percentage by $29.41 \%$ and $27.55 \%$ at concentrations 10 and $5 \mu \mathrm{g} / \mathrm{mL}$, respectively. Rest of all the groups showed significant change in elastin level after Biofield Energy Treatment compared with the untreated groups. Fibroblast and elastin are very important factors responsible for ageing. Data suggest that an increased elastin level that possibly enhances the elasticity and strength of the skin and activates the dermal metabolism. Therefore, the Biofield Energy Healing based test formulation and cell medium can be significantly used as an alternative approach in order to improve the elastin level that helps to improve cell growth, survival, differentiation and morphogenesis.

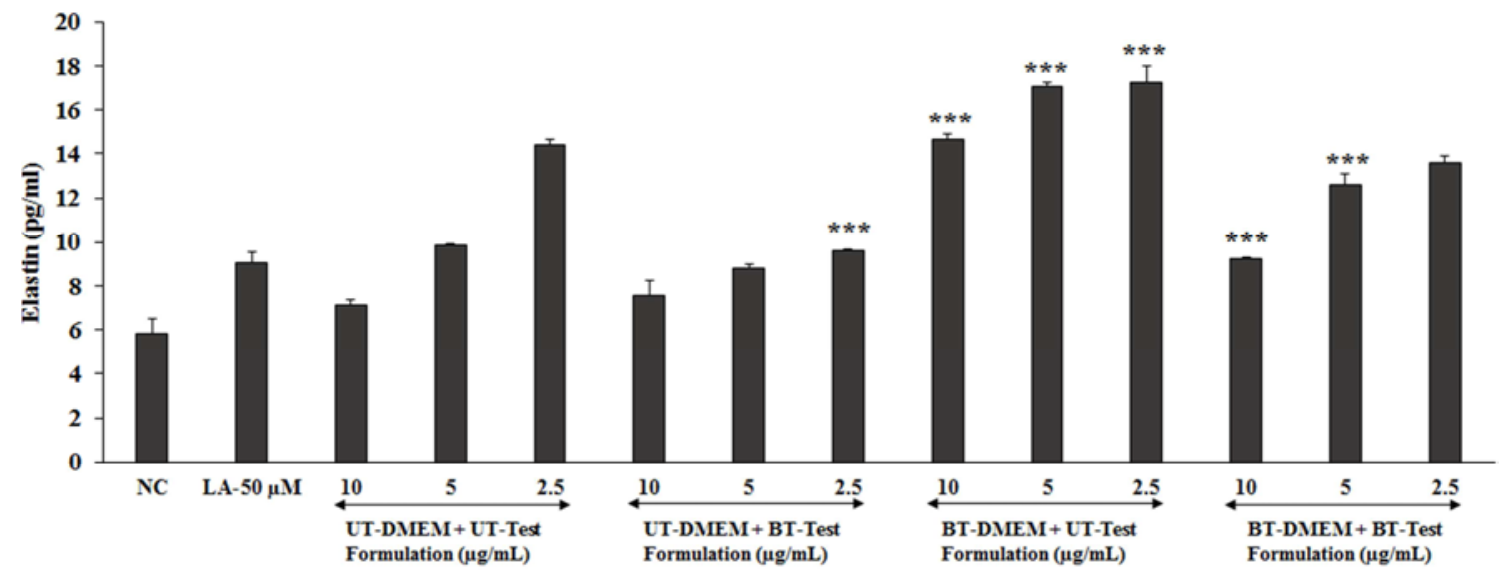

Figure 4. Concentration-dependent effect of Biofield Energy Treated test formulation on human dermal fibroblast (HFF-1) cell line for extracellular matrix component, elastin. ${ }^{* * *} \leq \leq 0.001$ statistical comparison with respect to untreated group using one way ANOVA (Dunnett's test). NC: Normal control; LA-50: LAscorbic acid at 50 $\mu \mathrm{M}$ concentration; UT: Untreated; BT: Biofield Treated.

Analysis of hyaluronic acid

Hyaluronic acid (HA) helps in retaining the skin moisture, and helps to stabilizes and regulates the skin water balance. $\mathrm{HA}$ is one of the important content of cosmetics products. The level of hyaluronic acid after Biofield Energy Treatment in the test formulation was evaluated in the HFF-1 cell line
(Figure 5). The results of ascorbic acid showed significant increase in the hyaluronic acid content by $183.6 \%$. However, untreated test formulation/DMEM group showed significant change in the HA levels in all the groups with respect to normal control group. After Biofield Energy Treatment, UT$\mathrm{DMEM}+\mathrm{BT}$-Test formulation group, at concentration 0.625 
$\mu \mathrm{g} / \mathrm{mL}$ showed increase in HA level by $5.19 \%$. However, all other experimental groups showed change in HA with respect to the baseline control. Hence, increased HA content using Biofield Energy Healing based test formulation would be a new approach in cosmetology. HA has been reported its importance in many products in order to improve the skin health [40]. Therefore, it might be expected that the Biofield Energy Healing based test formulation and Biofield Treated DMEM can be used to improve the content of hyaluronic acid. Hence, it can be concluded that The Trivedi Effect ${ }^{\circledR}$ has the capacity to regulate the skin moisture by maintain the HA level against many skin disorders.

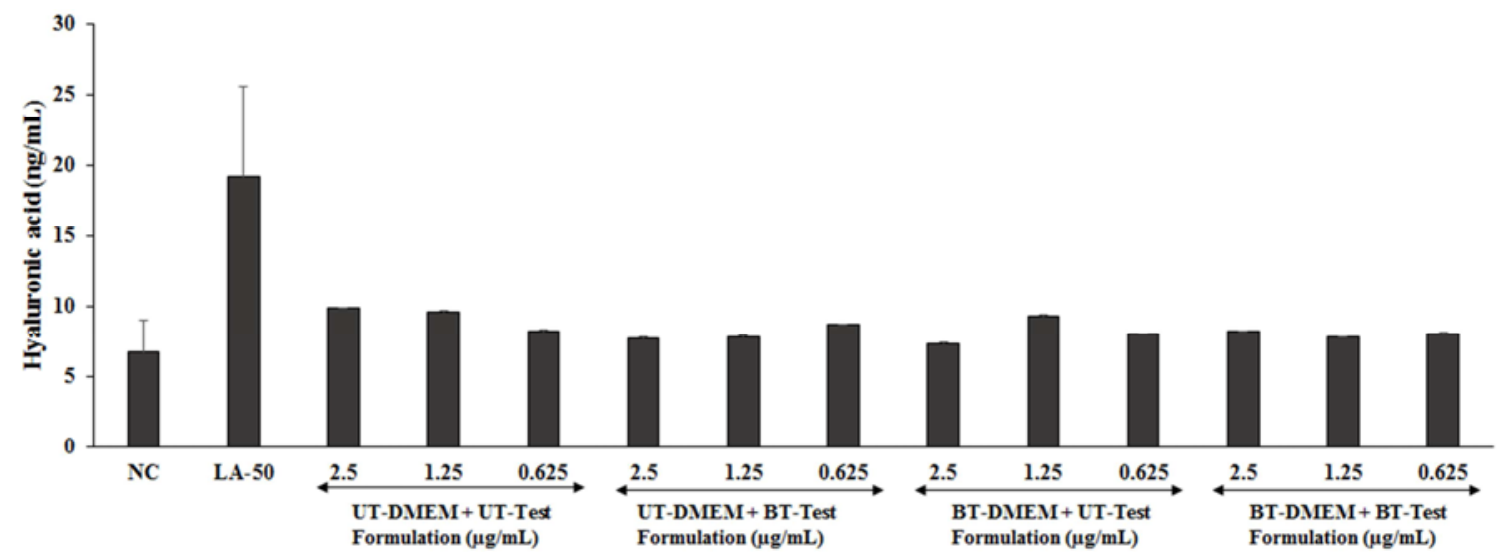

Figure 5. Synthesis of extracellular matrix component, hyaluronic acid by the Biofield Energy Treated test formulation in human dermal fibroblasts (HFF-1) cell lines. NC: Normal control; LA-50: L-Ascorbic acid at $50 \mu M$ concentration; UT: Untreated; BT: Biofield Treated.

\subsection{Estimation of Melanin Synthesis Inhibition}

Melanin, type of pigment produced by melanocytes skin cells and its produces in different shades and color depending upon the genetic makeup. Besides, sun ultraviolet radiations (UVA and UVB) initiated the process of melanogenesis in the melanocytes results in skin darkening. The effect of the Biofield Energy based herbomineral formulation on melanogenesis mouse melanoma (B16-F10) cell line was cultured in DMEM supplemented media containing several concentrations along with effect of kojic acid $(10 \mu \mathrm{M})$ for 48 to 96 hours. The results of percentage decrease in $\alpha$-MSH melanin synthesis in all the experimental groups are presented in Figure 6. Kojic acid, a skin whitening compound was used as positive control showed significant decreased level of melanin synthesis by $60.61 \%$. Besides, the Biofield Energy based test formulation showed significant decrease in the melanin synthesis by $14.16 \%$ in UTDMEM + BT-Test formulation group at $0.0625 \mu \mathrm{g} / \mathrm{mL}$ compared with the UT-DMEM + UT-Test formulation group. Besides, at concentration $0.125 \mu \mathrm{g} / \mathrm{mL}$, UT-DMEM + BT-Test formulation and BT-DMEM + UT-Test formulation groups showed decrease in melanin synthesis by $14.80 \%$ and $17.40 \%$ compared with the UT-DMEM + UT-Test formulation group in B16-F10 melanoma cell line. Biofield Energy Treated test formulation showed significant decrease in the level of melanin synthesis. This might be anticipated that tyrosinase enzymes activity was inhibited due to the Biofield Energy Treated Test formulation, which mainly responsible for melanin synthesis [41]. Many cosmetic formulation are used for skin whitening action by inhibiting the melanin synthesis, but they were full of side effects. However, test formulation was the combination of minerals, Centella asiatica extract and THC, also reported to have significant effect against skin infection, inflammatory dermatoses, with strong antioxidant action [42, 43]. Therefore, it can be concluded that the Biofield Energy Healing based herbomineral product and DMEM would be useful approach to decrease melanogenesis and would be a novel approach for skinrelated disorders with significant skin whitening action.

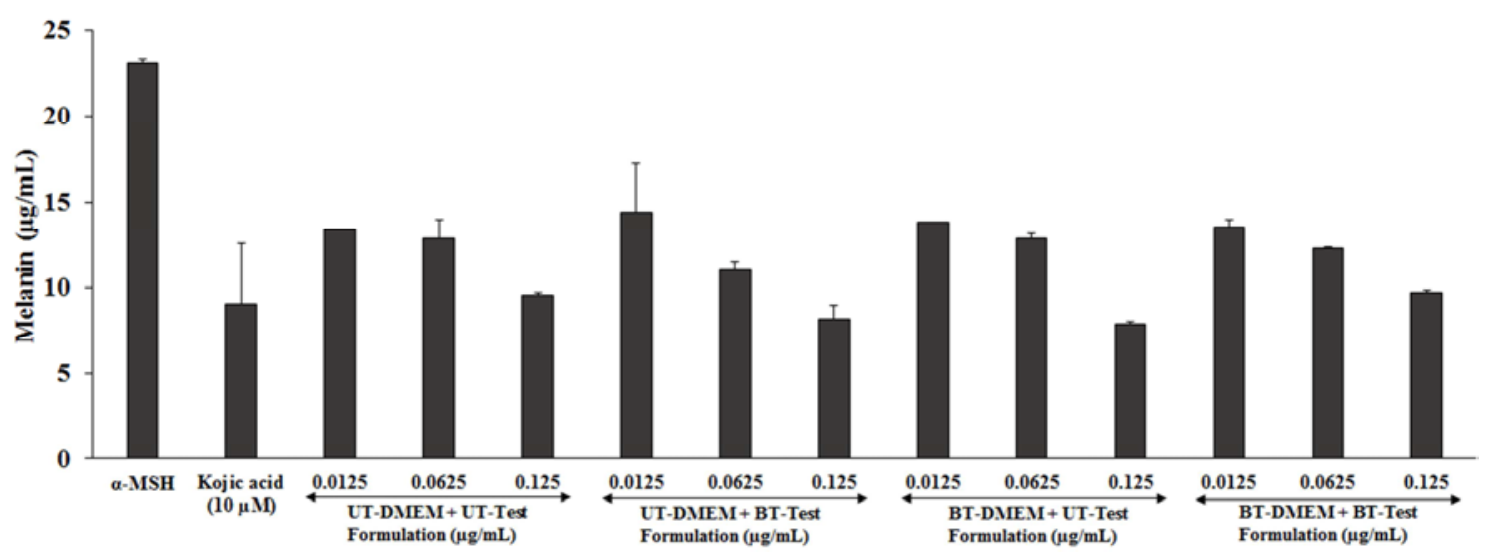

Figure 6. Inhibitory effect of the Biofield Energy Treated test formulation on melanogenesis (skin whitening potential) in mouse melanoma (B16-F10) cell line. UT: Untreated; BT: Biofield Treated. 


\subsection{Anti-Wrinkling Effects of Test Formulation on $U V-B$ Induced Photo Aging}

Cell viability potential of the Biofield Energy Treated test herbomineral formulation due to UV-B induced stress was measured in HFF-1 cells. UVB-induced various type of skin disorders, stress, free radical generation, etc. which all lead to downregulates the human skin fibroblasts results inflammatory responses, DNA damage, wrinkles, and skinageing [44]. Anti-wrinkling effect of cell viability from UV$\mathrm{B}$ rays is presented in Figure 7 . The HFF-1 cells were subjected to the lethal dose of UV-B irradiation $\left(200 \mathrm{~mJ} / \mathrm{cm}^{2}\right)$ and percentage cell viability due to UV-B was identified. The HFF-1 cells while exposure of UV-B reported with high degree of cell death with $25.21 \%$ of cell viability. The cell viability in vehicle control group was found as $27.78 \%$ due to UV-B irradiation $\left(200 \mathrm{~mJ} / \mathrm{cm}^{2}\right)$. However, ascorbic acid $(50$ $\mu \mathrm{M})$ showed significant increase in the cell viability i.e. $43.17 \%$. Besides, the experimental groups showed that all the groups in tested concentrations reported with improved cell viability. Among the tested groups, UT-DMEM + BT-Test formulation, BT-DMEM + UT-Test formulation, and BT-
DMEM + BT-Test formulation group at $0.625 \mu \mathrm{g} / \mathrm{mL}$ showed increase cell viability by $10.69 \%, 6.93 \%$, and $11.86 \%$, respectively compared with the UT-DMEM + UTTest formulation group. Similarly, UT-DMEM + BT-Test formulation, BT-DMEM + UT-Test formulation, and BT$\mathrm{DMEM}+\mathrm{BT}$-Test formulation groups at $1.25 \mu \mathrm{g} / \mathrm{mL}$ showed increased cell viability by $7.82 \%, 3.06 \%$, and $10.76 \%$, respectively compared with the UT-DMEM + UT-Test formulation group. In addition, UT-DMEM + BT-Test formulation and BT-DMEM + UT-Test formulation groups at $2.5 \mu \mathrm{g} / \mathrm{mL}$ showed increased cell viability by $11.7 \%$ and $14.99 \%$, respectively compared with the UT-DMEM + UTTest formulation group. UV-B induced skin damaged results in loss in cell viability, while experimental data suggest improved cell viability by Biofield Energy Healing based test formulation. Therefore, it can be expected that the Biofield Energy Treated Test formulation would be a better alternative treatment for skin protection and cell viability from UV-B radiations besides improved ECM components and hence results in the improved skin health with anti-wrinkling potential.

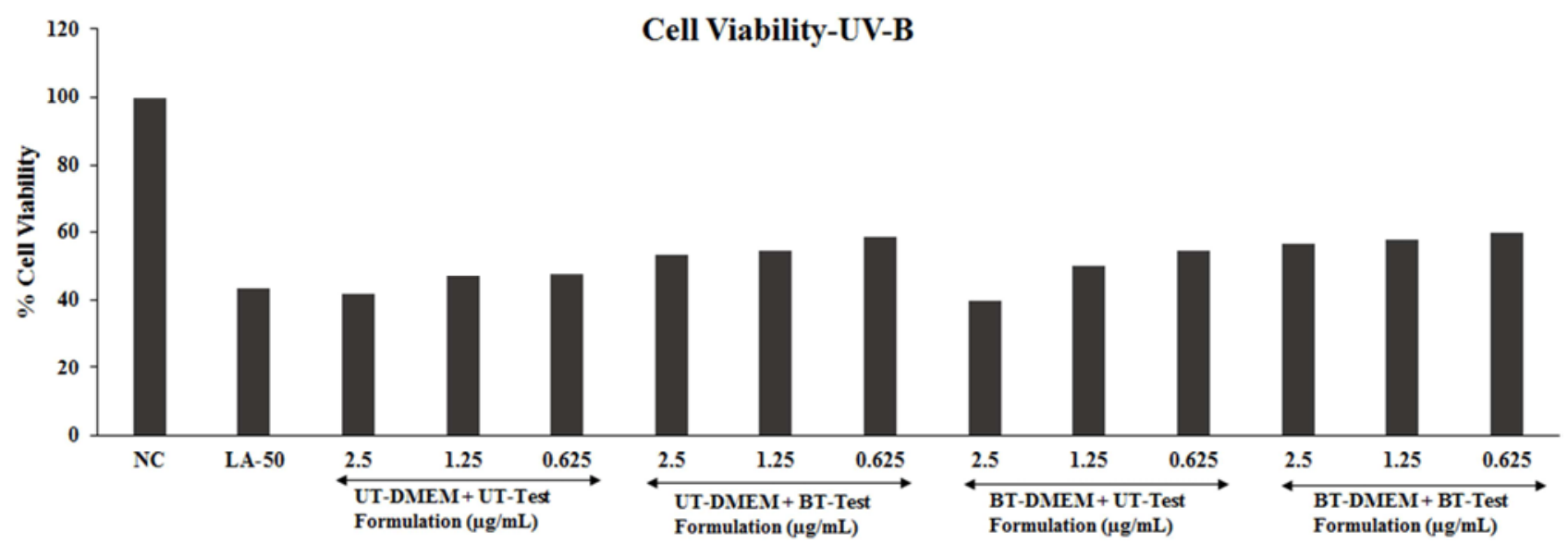

Figure 7. Anti-wrinkling potential and cytoprotective potential of Biofield Energy Treated test formulation against UV-B induced stress in human dermal fibroblasts (HFF-1) cell lines. \% cell viability of HFF-1 cells after treatment in various groups. NC: Normal control; LA-50: L-Ascorbic acid at 50 $\mu M$ concentration. UT: Untreated; BT: Biofield Treated.

\subsection{Wound-Healing Scratch Assay}

The effect of the Biofield Energy Healing based test formulation on HFF-1 and HaCaT cells were evaluated for wound healing activity using scratch assay. In vitro scratch assay model for wound healing determined the cellular migration, and defines the cell-to-cell and cell-to-matrix interactions during wound healing [45]. The representative cell migration photographs in different groups were monitored and shown in Figure 8. The scratched monolayer showed significant migration after treatment with the Biofield Energy Healing based test formulation/DMEM compared with untreated Test formulation/DMEM group. The cell migration was reported at 72 hours in the presence of the Biofield Energy Treated Test formulation compared with the vehicle control and EGF group. The experimental data suggest that percentage cell covered area in the Biofield
Treated Test formulation group was significantly higher with improved healing rate compared with the Biofield Energy Treated DMEM. The migration rate of HFF-1 cells and $\mathrm{HaCaT}$ cells were significantly high in monitored scratch area for wound closure. HaCaT and HFF-1 cells showed $1 \%$ to $5 \%$ increase in coverage area in the BT-DMEM + BT-Test formulation group, with respect to the UT-DMEM + UT-Test formulation. Representative images of scratched wound area showed significant increase in wound healing in EGF group as shown in Figure 8 (b) when compared with the normal control group in Figure 8 (a). Similarly, in UT-DMEM + BTTest formulation and BT-DMEM + UT-Test formulation experimental group showed significant rate of cellular migration rate along with wound closure as shown in Figure 8 (d, e), compared with the UT-Test formulation + UTDMEM group. 


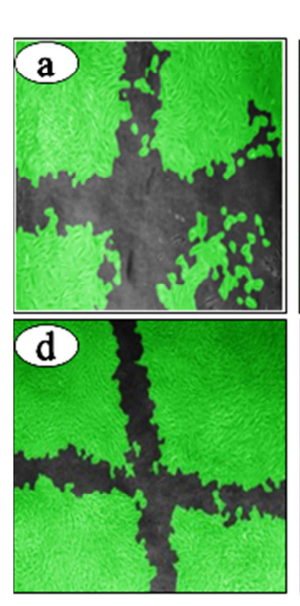

\section{HFF-1 Cells}

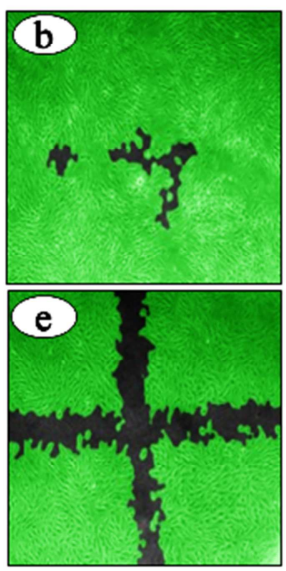

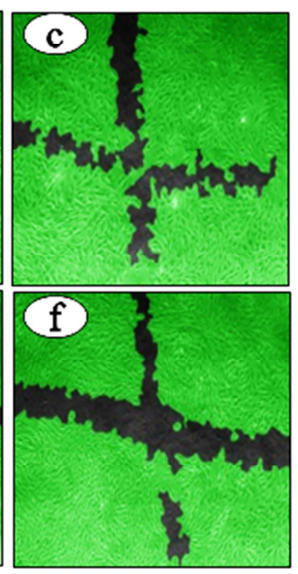

Figure 8. Representative pictures of HFF-1 and HaCaT cell migration cells after induction of a scratch. All the pictures were taken immediately after the scratch was induced (i.e. at 0 hours), after 24 hours in the presence of EGF and Biofield Energy Treated test formulation. Pictures are taken at 50 times magnification. Images represents HFF-1 cells migration in presence of (a) baseline control media, (b) EGF, (c) UT-DMEM + UT-Test formulation, (d) UT$D M E M+B T$-Test formulation, (e) BT-DMEM + UT-Test formulation, and BT-DMEM + BT-Test formulation.

Therefore, the Biofield Energy Healing based herbomineral formulation showed improved fibroblast migration, which might reflect improved collagen deposition results in improved wound healing. Collagen deposition results improved strength, integrity and structure to the skin. It might be suggested that the improved healing rate due to The Trivedi Effect ${ }^{\circledR}$ may be via antioxidant mechanism, which could be new alternative approach in wound healing.

\section{Conclusions}

Present experimental results showed significant impact of the Biofield Energy Healing based herbomineral test formulation and DMEM against various skin parameters. Cell viability using MTT assay showed that the Biofield Energy Healing based herbomineral test formulation was safe and nontoxic in all the tested concentrations. Fibroblast proliferation assay using BrdU assay in HFF-1 cells exhibited significant proliferation increased by $26.83 \%$ at $8.75 \mu \mathrm{g} / \mathrm{mL}$ in BT-Test formulation + BT-DMEM group compared with the untreated group. Collagen synthesis was improved by $22.05 \%$ and $22.24 \%$ at $2.5 \mu \mathrm{g} / \mathrm{mL}$ in the BT-DMEM + UTTest formulation and BT-DMEM + BT-Test formulation groups, respectively compared with untreated group. Besides, the level of elastin was found to be increased by $29.41 \%$ and $27.55 \%$ in BT-DMEM + BT-Test formulation group at 10 and $5 \mu \mathrm{g} / \mathrm{mL}$ respectively, compared to the UT-DMEM + UT-Test formulation group. However, the amount of hyaluronic acid was increased by $5.19 \%$ in UT-DMEM + BT-Test formulation group compared with the UT-DMEM + UT-Test formulation at concentration $0.625 \mu \mathrm{g} / \mathrm{mL}$. The melanin synthesis inhibition was found at $0.125 \mu \mathrm{g} / \mathrm{mL}$ by $14.80 \%$ and $17.40 \%$ in UT-DMEM + BT-Test formulation and BT-DMEM + UT-Test formulation groups, respectively compared with the UT-DMEM + UT-Test formulation group in B16-F10 melanoma cell line. However, the Biofield
Energy Treated Test formulation showed significantly improved anti-wrinkling effects using UV-B induced stress in HFF-1 cells by $11.7 \%$ and $14.99 \%$ in UT-DMEM + BTTest formulation and BT-DMEM + UT-Test formulation groups, respectively at $2.5 \mu \mathrm{g} / \mathrm{mL}$, while $10.69 \%, 6.93 \%$, and $11.86 \%$ in UT-DMEM + BT-Test formulation, BT-DMEM + UT-Test formulation, and BT-DMEM + BT-Test formulation groups, respectively at $0.625 \mu \mathrm{g} / \mathrm{mL}$ compared with the UTDMEM + UT-Test formulation group. Wound healing activity using scratch assay demonstrated significant migration of fibroblast and keratinocytes cells with increased covered area up to $5 \%$ after treatment with the Biofield Energy Healing based herbomineral test formulation in HFF1 and HaCaT cells. Hence, the Biofield Energy Treated test herbomineral formulation could be a better alternative approach against skin disorders through improved collagen, elastin, and hyaluronic acid synthesis with significant wound healing effect.

Overall, the Biofield Energy Treated test formulation can be used as a Complementary and Alternative Medicine (CAM) with a safe therapeutic index for various skin irregularities that are typically symptoms of a skin disorders such as Eczema, diaper rash, chickenpox, measles, warts, acne, hives, wrinkles, ringworm, Rosacea, psoriasis, seborrheic dermatitis, skin cancer, rashes from bacterial or fungal infections, rashes from allergic reactions, raised bumps that are red or white, cracked skin, discolored patches of skin, fleshy bumps, warts, or other skin growths, changes in mole color or size, a loss of skin pigment, scaly or rough skin, peeling skin, ulcers, open sores or lesions, dry, excessive flushing. Further, the Biofield Energy Healing based herbomineral test formulation can also be used in the prevention of temporary and permanent skin disorders, antiaging, improved overall health, and quality of life. 


\section{Acknowledgement}

Authors are grateful to Dabur Research Foundation, Trivedi Global, Inc., Trivedi Science, Trivedi Testimonials and Trivedi Master Wellness for their support throughout the work.

\section{References}

[1] Helmstädter A, Staiger C (2014) Traditional use of medicinal agents: a valid source of evidence. Drug Discov Today 19: 47.

[2] Fabricant DS, Farnsworth NR (2001) The value of plants used in traditional medicine for drug discovery. Environ Health Perspect 109: 69-75.

[3] Goyal RK (2005) Investigation of cellular and molecular mechanisms for anti-diabetic drugs with special reference to Unani and Ayurvedic herbal medicines. In: traditional system of medicine, Abdin, M. Z. and Y. P. Abrol (Eds.). Narosa Publishing House, New Delhi.

[4] WHO (1993) Research Guideline for Evaluating the Safety and Efficacy of Herbal Medicines. World Health Organization, Manila, Philippines.

[5] Gao XH, Zhang L, Wei H, Chen HD (2008) Efficacy and safety of innovative cosmeceuticals. Clin Dermatol 26: 36774.

[6] Chanchal D, Swarnlata S (2008) Novel approaches in herbal cosmetics. J Cosmet Dermatol 7: 89-95.

[7] Baumann L (2007) Skin ageing and its treatment. J Pathol 211: 241-251.

[8] Uitto J (1997) Understanding premature skin aging. N Engl J Med 337: 1463-1465.

[9] Gupta SC, Patchva S, Koh W, Aggarwal BB (2012) Discovery of curcumin, a component of golden spice, and its miraculous biological activities. Clin Exp Pharmacol Physiol 39: 283-299.

[10] Majeed M, Badmaev V, Uma S, Rajenderan JR (1995) Curcuminoids: Antioxidant Phytonutrients, Nutreiscience publishers New Jersey 1-24.

[11] Sugiyama Y, Kawakishi S, Osawa T (1996) Involvement of the $\beta$-diketone moiety in the antioxidant mechanism of tetrahydrocurcuminoids. Biochem Pharmacol 52: 519-525.

[12] Lai CS, Wu JC, Yu SF, Badmaev V, Nagabhushanam K, Ho CT, Pan MH (2011) Tetrahydrocurcumin is more effective than curcumin in preventing azoxymethane-induced colon carcinogenesis. Mol Nutr Food Res 55: 1819-1828.

[13] Boyera N, Galey I, Bernard BA (1998) Effect of vitamin C and its derivatives on collagen synthesis and cross-linking by normal human fibroblasts. Int J Cosmet Sci 20: 151-158.

[14] Park K (2015) Role of micronutrients in skin health and function. Biomol Ther (Seoul) 23: 207-217.

[15] Hashim P (2011) Centella asiatica in food and beverage applications and its potential antioxidant and neuroprotective effect. Int Food Res J 18: 1215-1222.

[16] Movaffaghia Z, Farsi M (2009) Biofield therapies:
Biophysical basis and biological regulations. Complement Ther Clin Pract 15: 35-37.

[17] Peck SD (1998) The efficacy of therapeutic touch for improving functional ability in elders with degenerative arthritis. Nurs Sci Q 11: 123-132.

[18] Giasson M, Bouchard L (1998) Effect of therapeutic touch on the well-being of persons with terminal cancer. J Holist Nurs 16: 383-398.

[19] Turner JG, Clark AJ, Gauthier DK, Williams M (1998) The effect of therapeutic touch on pain and anxiety in burn patients. J Adv Nurs 28: 10-20.

[20] Schlitz M, Hopf HW, Eskenazi L, Vieten C, Radin D (2012) Distant healing of surgical wounds: An exploratory study. Explore (NY) 8: 223-230.

[21] Trivedi MK, Bhardwaj Y, Patil S, Shettigar H, Bulbule A (2009) Impact of an external energy on Enterococcus faecalis [ATCC-51299] in relation to antimicrobials susceptibility and biochemical reactions-an experimental study. J Accord Integr Med 5: 119-130.

[22] Trivedi MK, Patil S, Shettigar H, Bairwa K, Jana S (2015) Phenotypic and biotypic characterization of Klebsiella oxytoca: An impact of biofield treatment. J Microb Biochem Technol 7: 203-206.

[23] Trivedi MK, Patil S, Shettigar H, Bairwa K, Jana S (2015) Effect of biofield treatment on phenotypic and genotypic characteristic of Provindencia rettgeri. Mol Biol 4: 129.

[24] Trivedi MK, Branton A, Trivedi D, Nayak G, Mondal SC, Jana S (2015) Evaluation of biochemical marker glutathione and DNA fingerprinting of biofield energy treated Oryza sativa. American Journal of BioScience 3: 243-248.

[25] Trivedi MK, Branton A, Trivedi D, Nayak G, Mondal SC, Jana S (2015) Evaluation of plant growth regulator, immunity and DNA fingerprinting of biofield energy treated mustard seeds (Brassica juncea). Agriculture Forestry and Fisheries 4: 269-274.

[26] Trivedi MK, Branton A, Trivedi D, Nayak G, Mondal SC, Jana S (2015) Evaluation of plant growth, yield and yield attributes of biofield energy treated mustard (Brassica juncea) and chick pea (Cicer arietinum) seeds. Agriculture, Forestry and Fisheries 4: 291-295.

[27] Altekar N, Nayak G (2015) Effect of biofield treatment on plant growth and adaptation. J Environ Health Sci 1: 1-9.

[28] Patil SA, Nayak GB, Barve SS, Tembe RP, Khan RR (2012) Impact of biofield treatment on growth and anatomical characteristics of Pogostemon cablin (Benth.). Biotechnology 11: 154-162.

[29] Trivedi MK, Patil S, Tallapragada RM (2013) Effect of biofield treatment on the physical and thermal characteristics of Silicon, Tin and Lead powders. J Material Sci Eng 2: 125.

[30] Trivedi MK, Patil S, Tallapragada RM (2014) Atomic, crystalline and powder characteristics of treated zirconia and silica powders. J Material Sci Eng 3: 144.

[31] Trivedi MK, Patil S, Tallapragada RMR (2015) Effect of biofield treatment on the Physical and Thermal Characteristics of Aluminium Powders. Ind Eng Manage 4: 151. 
[32] Plumb JA (2004) Cell sensitivity assays: the MTT assay. Methods Mol Med 88: 165-169.

[33] Hahn MS, Kobler JB, Starcher BC, Zeitels SM, Langer R (2006) Quantitative and comparative studies of the vocal fold extracellular matrix. I: Elastic fibers and hyaluronic acid. Ann Otol Rhinol Laryngol 115: 156-164.

[34] Zhang L, Yoshida T, Kuroiwa Y (1992) Stimulation of melanin synthesis of B16-F10 mouse melanoma cells by bufalin. Life Sci 51: 17-24.

[35] Shoulders MD, Raines RT (2009) Collagen structure and stability. Annual review of biochemistry 78: 929-958.

[36] Fronza M, Heinzmann B, Hamburger M, Laufer S, Merfort I (2009) Determination of the wound healing effect of Calendula extracts using the scratch assay with $3 \mathrm{~T} 3$ fibroblasts. J Ethnopharmacol 126: 463-467.

[37] Kadler KE, Holmes DF, Trotter JA, Chapman JA (1996) Collagen fibril formation. Biochemical Journal 316: 1-11.

[38] Shoulders MD, Raines RT (2009) Collagen structure and stability. Annual review of biochemistry 78: 929-958.

[39] Frantz C, Stewart KM, Weaver VM (2010) The extracellular matrix at a glance. J Cell Sci 123: 4195-4200.
[40] Weindl G, Schaller M, Schäfer-Korting M, Korting HC (2004) Hyaluronic acid in the treatment and prevention of skin diseases: molecular biological, pharmaceutical and clinical aspects. Skin Pharmacol Physiol 17: 207-213.

[41] Busca R, Ballotti R (2000) Cyclic AMP a key messenger in the regulation of skin pigmentation. Pigment Cell Res 13: 6069.

[42] Bylka W, Znajdek-Awiżeń P, Studzińska-Sroka E, Brzezińska M (2013) Centella asiatica in cosmetology. Postepy Dermatol Alergol 30: 46-49.

[43] Prasad S, Tyagi AK, Aggarwal BB (2014) Recent developments in delivery, bioavailability, absorption and metabolism of curcumin: the golden pigment from golden spice. Cancer Res Treat 46: 2-18.

[44] Ho JN, Lee YH, Lee YD, Jun WJ, Kim HK, Hong BS, Shin DH, Cho HY (2005) Inhibitory effect of Aucubin isolated from Eucommia ulmoides against UVB induced matrix metalloproteinase-1 production in human skin fibroblasts. Biosci Biotechnol Biochem 69: 2227-2231.

[45] Liang CC, Park AY, Guan JL (2007) In vitro scratch assay: A convenient and inexpensive method for analysis of cell migration in vitro. Nat Protoc 2: 329-333. 